\title{
Isolation and characterization of new microsatellite loci in Fenneropenaeus penicillatus
}

\author{
B.B. Li ${ }^{1,2}$, Z.B. Li ${ }^{1,2}$, Y.F. Ning ${ }^{1,2}$, J.B. Shangguan ${ }^{1,2}$, Y.S. Huang ${ }^{1,2}$, Y. Yuan ${ }^{1,2}$ and \\ X.Q. Mao, ${ }^{1,2}$ \\ ${ }^{1}$ Fisheries College, Jimei University, Xiamen, China \\ ${ }^{2}$ Fujian Provincial Key Laboratory of Marine Fishery Resources and Eco-Environment, \\ Xiamen, China \\ Corresponding author: Z.B. Li \\ E-mail: lizhongbao@jmu.edu.cn \\ Genet. Mol. Res. 15 (1): gmr.15017387 \\ Received August 6, 2015 \\ Accepted November 13, 2015 \\ Published March 24, 2016 \\ DOI http://dx.doi.org/10.4238/gmr.15017387
}

ABSTRACT. Fenneropenaeus penicillatus is one of the major economic shrimp species in China. In this study, 14 novel microsatellite loci were developed using the fast isolation protocol with amplified fragment length polymorphism of sequences containing repeats (FIASCO). Polymorphisms were tested in 30 individuals from a single-wild population. The results showed that the number of alleles at each locus ranged from two to four, and the polymorphism information content varied from 0.314 to 0.692 . The observed and expected heterozygosities ranged from 0.3343 to 0.6542 and from 0.3458 to 0.6657 , respectively. Three loci deviated significantly from Hardy-Weinberg equilibrium after a Bonferroni correction was applied, while no deviations were detected in the other 11 loci. The new microsatellite loci identified in this study could be useful in future F. penicillatus population genetic, conservation research, population structure assessment, and linkage map construction studies.

Key words: Genetic markers; Fenneropenaeus penicillatus; FIASCO; Microsatellite 


\section{INTRODUCTION}

Fenneropenaeus penicillatus, generally known as the red tail shrimp by the Food and Agriculture Organization (FAO), is an economically valuable species belonging to the Decapoda family Penaeidae. It is primarily distributed in the Indo-West Pacific, from Pakistan to Indonesia, and it is locally called "Jaira" on the Pakistan coast. In China, this species is mainly found in the southeastern coastal area, including Fujian, Guangdong, and Taiwan. The temperature and salinity tolerance of $F$. penicillatus is higher than other shrimps. Moreover, F. penicillatus was a popular fishing and aquaculture species before 2000 in China (Cao et al., 2012), because it was fresh, tender, large, brightly colored, high in protein, and low in fat. Furthermore, the species was also used for medicinal purposes. F. penicillatus is considered an endangered species (Wang and Xie, 2009), and it is on the Red List maintained by the Chinese government. In recent years, there was a considerable reduction of its wild stock, which is an important factor in F. penicillatus reproduction. Several factors are likely associated with this reduction, including excess exploitation, unreasonable utilization, habit damage, and environmental pollution. In order to preserve F. penicillatus wild stocks, it is imperative for researchers to comprehensively understand its hereditary constitution.

Microsatellites are simple-tandem repeat sequence motifs, which consist of repeat units ranging from 1 to $6 \mathrm{bp}$ in length. As genetic markers, they are widely distributed throughout the eukaryotic genome. Microsatellites consist of middle-core sequences and conservative flanking sequences. Moreover, these markers exhibit various advantages, such as co-dominance, high frequency of polymorphisms, and reliability, which are important elements when studying population genetics. Microsatellite markers are widely used in population differentiation, population genetics, linkage analyses, and evolutionary studies (Li, 2006). Microsatellite markers in other shrimps have been reported, including Litopenaeus vannamei (Garcla and Alcivar-Warren, 1996), Penaeus monodon (Xu et al., 2001), F. chinensis (Meng et al., 2009), and Macrobrachium nipponense (Ma et al., 2010). To the best of our knowledge, there are a few reports referring $F$. penicillatus, while major studies focusing on the cultural ecology, basic biology, as well as breeding (Zhang et al., 2010). Thus, the results of this study of $F$. penicillatus population genetics could be utilized in future research examining the improvement and conservation of the species.

\section{MATERIAL AND METHODS}

The microsatellite markers were developed using the fast isolation protocol with amplified fragment length polymorphism of sequences containing repeats (FIASCO) protocol (Zane et al., 2002). Using CTAB methods (Zhao et al., 2011), high-quality genomic DNA was extracted from the muscular tissue of a single wild F. penicillatus individual that was captured in Zhanjiang, China. Genomic DNA (100 ng/ $\mu \mathrm{L}$ ) was digested with the restriction enzyme FastDigest Trull (Fermentas, Canada) at $37^{\circ} \mathrm{C}$ for $5 \mathrm{~min}$, and the enzyme was then inactivated by heating for 5 min at $65^{\circ} \mathrm{C}$. The digested fragments, ranging from 400 to $1200 \mathrm{bp}$, were then ligated to Msel adapter $\mathrm{A}$ (5'-ACGATGAGTCCTGAG-3')/Msel adapter B (5'-TACTCAGGACTCAT-3') using T4 DNA ligase (Ferments, Vilnius, Lithuania) at $22^{\circ} \mathrm{C}$ overnight. The linker-ligated mixture was denatured at $95^{\circ} \mathrm{C}$ for $10 \mathrm{~min}$. Afterwards, the digestion-ligation fragments were hybridized to the biotinylated probes $(\mathrm{CT})_{15}$ and $(\mathrm{GT})_{15}$ at $61^{\circ} \mathrm{C}$ for $1 \mathrm{~h}$. Fragments containing microsatellite repeats were captured with Streptavidin-coated Magnetic Sphere Particles (Promega, Madison, WI, USA), and the noncaptured DNA fragments were washed away. The recovered DNA fragments were amplified using Msel adapter A. Polymerase chain reaction (PCR) products were purified using GenCleanPCR 
(Generay, Shanghai, China) to remove the extra adapters and dNTPs. The purified products were ligated to the PMD19-T vector (Takara, Shiga, Japan) at $16^{\circ} \mathrm{C}$ for $3.5 \mathrm{~h}$, and they were transformed into Escherichia coli DH5 $\alpha$ (Tiangen, China) competent cells and incubated overnight at $37^{\circ} \mathrm{C}$ in a constant temperature oven. Transformants were cultured on lysogeny broth agar plates containing ampicillin $(60 \mathrm{mg} / \mathrm{mL})$. The positive clone fragments were amplified using M13 universal primers, and the PCR products were determined using 1\% agarose gel electrophoresis. A total of 138 positive clones, with DNA fragment bands ranging from 500 to $1200 \mathrm{bp}$, were sequenced by Invitrogen (Guangzhou, China).

After the sequence analysis, 67 clones containing microsatellites were found using the SSRhunter 1.3 software, and 49 pairs of primers were designed using the Primer Premier 5.0 software. Thirty-six primer pairs were successfully selected for testing by amplifying the genomic DNA of 30 wild $F$. penicillatus individuals collected from Zhanjiang, China. PCR amplification was carried out in $10-\mu \mathrm{L}$ reaction mixtures containing 50 ng genomic DNA, 10X Taq buffer, $2 \mathrm{mM} \mathrm{MgCl}$, $0.4 \mu \mathrm{M}$ forward primer, $0.4 \mu \mathrm{M}$ reverse primer, $0.25 \mathrm{U}$ Taq DNA polymerase (Fermentas), and 0.2 $\mathrm{mM}$ of each dNTP. The PCR amplification was performed under the following conditions: initial denaturation at $94^{\circ} \mathrm{C}$ for $5 \mathrm{~min} ; 32$ cycles of denaturation at $94^{\circ} \mathrm{C}$ for $30 \mathrm{~s}$, annealing at the optimal temperature (Table 1) for $30 \mathrm{~s}$, and $72^{\circ} \mathrm{C}$ for $1 \mathrm{~min}$; a final extension step at $72^{\circ} \mathrm{C}$ for $10 \mathrm{~min}$; and samples were then held at $4^{\circ} \mathrm{C}$. All PCR products were separated and visualized using $\mathrm{Qsep}_{100}$ of the capillary gel electrophoresis system (BiOptic Inc., Taiwan). Finally, using the POPGENE 32 (version 1.32) software (Yeh et al., 2000), important genetic information was analyzed to estimate the number of alleles per locus, the observed heterozygosity, the expected heterozygosity, and Hardy-Weinberg equilibrium (HWE). Polymorphic information content (PIC) was estimated using the CERVUS (version 3.0) software.

\section{RESULTS AND DISCUSSION}

We successfully isolated 14 polymorphic microsatellite loci (Table 1) in F. penicillatus. The number of polymorphic alleles per locus ranged from two to four, and the PIC varied from 0.314 to 0.692 . The observed and expected heterozygosity values ranged from 0.3343 to 0.6542 and from 0.3458 to 0.6657 , respectively. After applying the Bonferroni correction $(k=14)$, eleven of the 14 loci were in Hardy-Weinberg equilibrium ( $P>0.0036)$, with the exception of CMX2-38, CMX2-63, and CMX2-109.

The average number of polymorphic alleles per locus was 3.5 , which was similar to the result of Cao et al. (2012) for F. penicillatus, but it was lower than that reported for other shrimps (Xu et al., 2001; Meng et al., 2009; Ma et al., 2010). The PIC value is an important indicator that measures the extent of polymorphism for marker genes or marker sequences (Lü, 1994). When the PIC value is below 0.25, the population has fewer polymorphisms. When the PIC value ranges between 0.25 and 0.5 , the polymorphisms of a population can be considered moderate, and high frequency of polymorphism is denoted by PIC values above 0.5 (Botstein et al., 1980). In this study, we found seven loci with moderate polymorphisms (CMX26, CMX2-16, CMX2-25, CMX2-69, CMX2-109, CMX53, and CMX60) and seven loci with high frequency of polymorphisms (CMX2-38, CMX2-45, CMX2-63, CMX2-101, CMX2-102, CMX15, and CMX22).

In summary, the 14 novel polymorphic microsatellite loci identified in this study could be useful, to some extent, for future F. penicillatus population genetic, conservation research, and population structure studies. 
Table 1. Characterization of 14 microsatellite loci isolated from Fenneropenaeus penicillatus.

\begin{tabular}{|c|c|c|c|c|c|c|c|c|c|}
\hline $\begin{array}{l}\text { GenBank } \\
\text { accession No. }\end{array}$ & Locus ID & Primer sequences $\left(5^{\prime}-3^{\prime}\right)$ & $\begin{array}{c}\text { Repeat } \\
\text { motif }\end{array}$ & $\begin{array}{c}\mathrm{Ta} \\
\left({ }^{\circ} \mathrm{C}\right)\end{array}$ & $N_{\mathrm{A}}$ & $\begin{array}{l}\text { Allele size } \\
\text { (bp) }\end{array}$ & PIC & $\mathrm{Ho}_{\mathrm{O}}$ & $\mathrm{HE}_{\mathrm{E}}$ \\
\hline KT318837 & CMX2-6 & $\begin{array}{l}\text { F: GCATCATATTGCGTTTG } \\
\text { R: AATCTCACTGCCACCAC }\end{array}$ & $(\text { TCCTCT })_{3}$ & 48.8 & 3 & $233-248$ & 0.570 & 0.3429 & 0.6571 \\
\hline KT318838 & CMX2-16 & $\begin{array}{l}\text { F: GCACGCATACCGAACTCT } \\
\text { R: ACTGCCACCACCCATTTA }\end{array}$ & $(\mathrm{CA})_{8}$ & 53.2 & 4 & $174-182$ & 0.692 & 0.3343 & 0.6657 \\
\hline KT318839 & CMX2-25 & $\begin{array}{l}\text { F: GGATACGGAAGAATAAGG } \\
\text { R: GCAAGCAGACGAATACA }\end{array}$ & $(\mathrm{AGAT})_{3}$ & 51.0 & 4 & $174-228$ & 0.504 & 0.5115 & 0.4885 \\
\hline KT318840 & CMX2-38 & $\begin{array}{l}\text { F: TATCTTTCCGCCATCTTTGA } \\
\text { R: GCTGAATAAGAACGCCTGTG }\end{array}$ & $(\mathrm{CT})_{5}$ & 48.8 & 4 & $142-158$ & 0.415 & 0.4944 & $0.5056^{*}$ \\
\hline KT318841 & CMX2-45 & $\begin{array}{l}\text { F: ACCATCATTTTCAAACCA } \\
\text { R: GGGAAGACAGTGCCATC }\end{array}$ & $(\mathrm{CAC})_{4}$ & 51.0 & 2 & 145 & 0.368 & 0.5056 & 0.4944 \\
\hline KT318842 & CMX2-63 & $\begin{array}{l}\text { F: AGACCAATAAAGCACTAAA } \\
\text { R: CAGGACGATAGACTGACA }\end{array}$ & $(\text { ATC })_{4}$ & 51.0 & 3 & $220-246$ & 0.342 & 0.6136 & $0.3864^{*}$ \\
\hline KT318843 & CMX2-69 & $\begin{array}{l}\text { F: GGGAAGGTAGGGACTAA } \\
\text { R: ATGTACTGCCATCTGCT }\end{array}$ & $(A G)_{6}$ & 48.8 & 4 & $120-136$ & 0.573 & 0.5423 & 0.4577 \\
\hline KT318844 & CMX2-101 & $\begin{array}{l}\text { F: AGACTACGGCAGAACTT } \\
\text { R: AGGATTATAGGCGACAG }\end{array}$ & $(\mathrm{TCC})_{4}$ & 48.8 & 4 & $301-310$ & 0.446 & 0.6254 & 0.3746 \\
\hline KT318845 & CMX2-102 & $\begin{array}{l}\text { F: GAAGACAGTGCCATCCC } \\
\text { R: CCATCATTTTCAAACCAT }\end{array}$ & $(\text { TGG })_{4}$ & 51.0 & 3 & $151-195$ & 0.475 & 0.4599 & 0.5401 \\
\hline KT318846 & CMX2-109 & $\begin{array}{l}\text { F: GAGGATTATAGGCGACAGG } \\
\text { R: AGACTACGGCAGAACTTGG }\end{array}$ & $(\mathrm{GGA})_{4}$ & 55.5 & 4 & $278-301$ & 0.618 & 0.3513 & $0.6487^{*}$ \\
\hline KT318847 & CMX15 & $\begin{array}{l}\text { F: CGTGGTCAGCGAAGAAC } \\
\text { R: ACCGACAGGCAAATCAA }\end{array}$ & $(\mathrm{GT})_{6}$ & 43.0 & 3 & $186-200$ & 0.383 & 0.5684 & 0.4316 \\
\hline KT318848 & CMX22 & $\begin{array}{l}\text { F: TTGACATTATTACTATCGTG } \\
\text { R: CACAGCAAAAGGTACAG }\end{array}$ & $(\text { ATGATA })_{3}$ & 59.0 & 3 & $270-300$ & 0.314 & 0.6542 & 0.3458 \\
\hline KT318849 & CMX53 & $\begin{array}{l}\text { F: AGAATGGATGTCAAGGAG } \\
\text { R: CACATAAACAAAGAGGAAA }\end{array}$ & $(\text { GTCT })_{3}$ & 49.0 & 4 & $205-222$ & 0.566 & 0.5691 & 0.4309 \\
\hline KT31 & CMX60 & $\begin{array}{l}\text { F: TCACTTCGTCATTCCC } \\
\text { R: AACAGACAAGCAAACCT }\end{array}$ & A) 3 & 44.5 & 4 & 329 & 0.615 & 0.4718 & 0.5282 \\
\hline
\end{tabular}

$\mathrm{Ta}=$ annealing temperature; $N_{\mathrm{A}}=$ number of polymorphic alleles per locus; $\mathrm{PIC}=$ polymorphism information content; *indicates significant departure $(P<0.0036)$ from expected Hardy-Weinberg equilibrium after multiple correction tests $(\mathrm{k}=14) ; H_{\mathrm{O}}=$ observed heterozygosity; $H_{\mathrm{E}}=$ expected heterozygosity.

\section{Conflicts of interest}

The authors declare no conflict of interest.

\section{ACKNOWLEDGMENTS}

Research supported by the National Natural Science Foundation of China (\#31272668), the Natural Science Foundation of Fujian Province (\#2010J01213), the Program of Fujian Provincial Department of Science and Technology (\#JK2010034), the Program for New Century Excellent Talents in Fujian Province University, and the Foundation for Innovative Research Team of Jimei University, China (\#2010A004).

\section{REFERENCES}

Botstein D, White RL, Skolnick M and Davis RW (1980). Construction of a genetic linkage map in man using restriction fragment length polymorphisms. Am. J. Hum. Genet. 32: 314-331.

Cao YY, Li ZB, Li QH, Dai G, et al. (2012). Development and characterization of microsatellite loci for Fenneropenaeus penicillatus Aclock. Afr. J. Biotechnol. 11: 10831-10833.

Garcia DK and Alcivar-Warren A (1996). Identification and organization of microsatellite in Penaeus vannamel shrimp. Proceedings of the XXVth International Conference on Animal Genetics.

Li Q (2006). Development of microsatellite DNA markers and their applications in genetic studies of marine mollusks. J. Fish. Sci. China 3: 502-509.

Lǔ́ BZ (1994). Does the polymorphism information content equal the heterozygosity. Hereditas 16: 31-33. 
Ma KY, Feng JB, Li JL and Ding HY (2010). Twenty-four novel polymorphic microsatellite markers from oriental river prawn (Macrobrachium nipponense). Conserv. Genet. Resour. 2: 125-128. http://dx.doi.org/10.1007/s12686-010-9236-z

Meng XH, Wang QY, Jang IK, Liu P, et al. (2009). Genetic differentiation in seven geographic populations of the fleshy shrimp Penaeus (Fenneropenaeus) chinensis based on microsatellite DNA. Aquaculture 287: 46-51. http://dx.doi.org/10.1016/j. aquaculture.2008.10.030

Wang S and Xie Y (2009). China species red list, 1st vol. China Higher Education Press, Beijing.

Xu ZK, Primavera JH, Pena LD, Pettit P, et al. (2001). Genetic diversity of wild and cultured Black Tiger Shrimp (Penaeus monodon) in the Philippines using microsatellites. Aquaculture 199: 13-40. http://dx.doi.org/10.1016/S00448486(00)00535-4

Yeh FC, Yang R, Boyle TJ, Ye Z, et al. (2000). PopGene32, Microsoft Windows-Based freeware for population genetic analysis, version 1.32. Molecular Biology and Biotechnology Centre University of Alberta, Alberta.

Zane L, Bargelloni L and Patarnello T (2002). Strategies for microsatellite isolation: a review. Mol. Ecol. 11: 1-16.http://dx.doi. org/10.1046/j.0962-1083.2001.01418.x

Zhang GL, Li ZB, Wang ZL, Lin XY, et al. (2010). Study status and perspective of Fenneropenaeus penicillatus. Mod. Fish. Inform. 25: 7-10.

Zhao RJ, Yan HY, Tan YP, Wang CY, et al. (2011). Animal DNA extraction with CTAB method. Sci. Technol. West China 10: 7-8. 